\title{
Hubungan Pola Makan Dengan Proses Penyembuhan Luka Episiotomi
}

\author{
Siti Muniroh \\ Prodi D-III Keperawatan Fakultas Ilmu Kesehatan Unipdu Jombang
}

\begin{abstract}
ABSTRAK
Episiotomi atau istilah yang paling tepat adalah perineotomi. Episiotomi adalah tindakan mengiris atau menggunting perineum dengan tujuan untuk memperlancar proses persalinan, tetapi tidak semua ibu memerlukan episiotomi untuk persalinan, namun pengalaman yang matang diperlukan untuk menentukan kapan episiotomi tidak di perlukan. Tujuan penelitian ini untuk mengetahui hubungan antara pola makan ibu postpartum dengan fase penyembuhan luka episiotomi di BPM Hj. Umi Salamah Peterongan Jombang. Penelitian ini deskriptif analitik dengan pendekatan cross sectional. Sampel penelitian ini ibu yang melahirkan dan kontrol di BPM Hj. Umi Salamah Peterongan Jombang dengan episiotomi berjumlah 18 responden, menggunakan teknik accidental sampling. Variabel independennya adalah pola makan ibu postpartum dan variabel dependennya adalah fase penyembuhan luka episiotomi. Pengumpulan data dengan kuesioner dan observasi kemudian dianalisis dengan uji SPSS spearman's correlation $\rho \leq 0,05$. Pola makan ibu postpartum dalam kategori makan gizi seimbang sebanyak 17 responden $(94,5 \%)$, dan fase penyembuhan luka pada ibu postpartum yang berada pada fase inflamasi sejumlah 13 responden (72,2\%). Hasil uji spearman's correlation $\rho=0,046$ yang berarti ada hubungan antara pola makan ibu postpartum dengan penyembuhan luka episiotomy di BPM $\mathrm{Hj}$. Umi Salamah Peterongan Jombang. Sehingga diharapkan bagi ibu postpartum untuk makan makanan dengan gizi seimbang dan rajin kontrol ke pelayanan kesehatan.
\end{abstract}

Kata kunci: pola makan, fase penyembuhan luka, ibu postpartum

\begin{abstract}
Episiotomy is a term for a perineal incision or the type of operative actions of the most widely performed on maternal, but not all women require an episiotomy for child birth, but the mature experiences is needed to determine when an episiotomy is not necessary. The study was conducted to determine the relationship partum maternal diet with an episiotomy wound healing phase in BPM Hj. Umi Salamah Peterongan Jombang.

This type of research is deskriptif analytic cross sectional approach. Sample is a mother giving birth and controls in BPM Hj. Umi Salamah Peterongan Jombang, who experienced episiotomy, amounting to 18 respondens, using the technique accidental sampling. Independent variablesin this study werepost partubm maternal diet and the dependent variable is the phase of wound healing episiotomy. Data collection by questionnaires and observations were analyzed using SPSS spearman's correlation $\rho \leq 0$ 05.

Postpartum maternal diet in the category of nutritional balanced meal as much as 17 respondents (94,5\%), and the phase of wound healing in postpartum women who are at the inflammatory phase of a number of 13 respondents (72,2\%). The results of the study with SPSS spearman's correlation showed a value of $\rho=0.046$. Means $\rho<0.05$, which meansthat $H_{0}$ is rejected, so there is a relationship between postpartum maternal diet with an episiotomy wound healing in the BPM Hj. Umi Salamah Peterongan Jombang. This suggests that a diet with balanced nutrition can influence the phase of wound healing episiotomy. For mothers postpartum expected to eat a balanced diet, and diligent control to health care.
\end{abstract}

Keywords: diet, wound healing 


\section{PENDAHULUAN}

Episiotomi atau istilah yang paling tepat adalah perineotomi. Episiotomi adalah tindakan mengiris atau menggunting perineum dengan tujuan untuk memperlancar proses persalinan (Rukiyah, 2009), tetapi tidak semua ibu memerlukan episiotomi untuk persalinan, namun pengalaman yang matang diperlukan untuk menentukan kapan episiotomi tidak di perlukan. Walaupun hanya sedikit bukti ilmiah yang mendukung penggunaanya, tetapi pada tahuntahun terakhir ini keuntungan episiotomi secara rutin tersebut mulai dipertanyakan. Tindakan invasif ini bukan tanpa resiko, tetapi dapat menimbulkan beberapa resiko di antaranya;

Resiko terjadinya perdarahan yang lebih besar saat persalinan, proses penyembuhan biasanya lebih nyeri dan lebih lama dibandingkan robekan spontan, meningkatkan resiko terjadinya infeksi, bagi beberapa wanita akan merasakan nyeri saat berhubungan seksual selama beberapa bulan setelah melahirkan, resiko terjadinya robekan pada persalinan berikutnya lebih besar, inkontinensia anus. Indikasi lain untuk episiotomi guna mencegah terjadinya pendarahan intrakranial pada bayi baru lahir. Dari tindakan episiotomi tersebut dapat menimbulkan luka atau terputusnya jaringan (Higuera.V, 2016).

Proses penyembuhan luka episiotomi biasanya bervariasi, ada yang cepat dan lambat, hal ini dapat dipengaruhi beberapa faktor diantaranya yaitu: kondisi fisik ibu bersalin, status gizi, kondisi luka dan perawatannya (Rukiyah, 2009). Menurut penelitian yang dilakukan (Yasmalizar, 2013) bahwa asupan makanan yang bergizi dan porsi yang sesuai dapat mempengaruhi percepatan penyembuhan luka perineum.

terhadap proses penyembuhan luka pada perineum dan penggantian jaringan yang sangat membutuhkan protein.

Penggunaan episiotomi, yang dahulu merupakan praktek standar sudah makin berkurang pada tahun-tahun terakhir ini. Ada beberapa tenaga kesehatan yang masih melakukan episiotomi rutin sebesar $70 \%$ tetapi sebagian besar pemberi perawatan umumnya

Desain penelitian menggunakan deskriptif analitik dengan pendekatan cross-sectional. mempunyai angka pengunaan episiotomi $30 \%$. Untuk keadaan ini ada masalah saat pelahiran, angka episiotomi adalah 10\%-20\%. Besarnya angka pengunaan episiotomi di kalangan bidan adalah dibawah $10 \%$. Alasan menurunya penggunaan ini adalah penelitian ilmiah yang dilakukan pada tahun 1990an yang menunjukkan bahwa episiotomi rutin tidak bermanfaat dan malah beresiko (Holmes, 2011).

Tujuan dilakukan tindakan episiotomi diantaranya adalah mencegah robekan yang luas dan tidak beraturan pada daerah perineum. Adapun keuntungannya adalah lebih mudah dijahit serta hasilnya lebih baik, sedangkan kerugiannya adalah resiko terjadi robekan yang meluas sampai ke anus. Tindakan episiotomi ini paling sering dilakukan pada primipara karena jalan lahirnya kurang elastis dan sukar meregang.

Tetapi tidak menutup kemungkinan pada persalinan kedua dan ketiga juga memerlukan tindakan episiotomi jika bayi yang kedua,atau yang ke tiga, terlalu besar, perineum kaku, persalinan sungsang (Prawirohardjo, 2010).

Bebarapa hal yang dapat dilakukan sebelum atau selama persalinan untuk melindungi perinium, dan menghindari tindakan episiotomi: makan makanan yang bergizi selama kehamilan, karena nutrisi atau pola makan yang baik mendukung jaringan yang sehat, lakukan pijat perinium secara teratur selama beberapa minggu sebelum pelahiran, selama mengejan, gunakan tekanan kebawah yang sepontan atau tekanan yang singkat (lima sampai tujuh detik), selama pelahiran, gunakan posisi yang membuat pelahiran yang lebih efisien, selama pelahiran, bekerja samalah dengan memberi perawatan dan gunakan gerak pernafasan ringan untuk menghindari penekanan sementara kepala dan bahu bayi keluar (Bahiyatun, 2009).

Berdasarkan data yang diambil dari BPM Hj. Umi Salamah Peterongan Jombang didapatkan data tentang tindakan episiotomi mulai Januari sampai dengan Desember 2017 sebanyak 43 orang dari 93 orang yang melahirkan.

\section{BAHAN DAN METODE}

Waktu pengukuran atau observasi data pada variabel independen dan dependen dilakukan 
bersamaan (Notoatmojdo, 2010). Tempat penelitian di BPM Hj. Umi Salamah Peterongan Jombang. Waktu penelitian Maret 2019.

Variabel independen penelitian ini: pola makan ibu nifas dengan episiotomi. Variabel dependen penelitian ini: penyembuhan luka episiotomi dengan kriteria :luka kering, tidak terdapat tanda-tanda infeksi (nyeri, kemerahan),

\section{HASIL}

1. Data Umum

Tabel 1 Distribusi Frekuensi Responden Berdasarkan Umur Pasien

\begin{tabular}{cccc}
\hline No & $\begin{array}{c}\text { Umur Pasien } \\
\text { (tahun) }\end{array}$ & Frekuensi & $\begin{array}{c}\text { Prosentase } \\
(\%)\end{array}$ \\
\hline 1. & $<20$ & 1 & 5,5 \\
2. & $20-30$ & 16 & 88,9 \\
3. & $>30$ & 1 & 5,5 \\
\hline & Jumlah & 18 & $100 \%$ \\
\hline
\end{tabular}

Sumber : Hasil observasi data responden

Berdasarkan tabel 1 didapatkan data hampir seluruhnya responden dengan usia 20-30 tahun sejumlah 16 orang $(88,9 \%)$

Tabel 2 Distribusi Frekuensi Responden Berdasarkan pendidikan Pasien

\begin{tabular}{cccc}
\hline No. & Pendidikan & Frekuensi & Prosentase \\
\hline 1. & SD & 2 & 11,1 \\
2. & SLTP & 2 & 11,1 \\
3. & SLTA & 10 & 55,6 \\
4. & Perguruan & 4 & 22,2 \\
& Tinggi & & \\
\hline & Jumlah & 18 & $100 \%$
\end{tabular}

Sumber : Hasil observasi data responden

Didapatkan data sebagian besar responden pendidikan SMA sejumlah 10 orang $(55,6 \%)$.

Tabel 3 Distribusi Frekuensi Responden Berdasarkan Pekerjaan Pasien

\begin{tabular}{cccc}
\hline No. & Pekerjaan & Frekuensi & $\begin{array}{c}\text { Prosentase } \\
(\%)\end{array}$ \\
\hline 1. & Tani & 0 & 0 \\
2. & PNS & 1 & 5,5 \\
3. & Swasta & 3 & 16,7 \\
4. & IRT & 14 & 77,8 \\
\hline & Jumlah & 18 & 100 \\
\hline
\end{tabular}

Sumber : Hasil observasi data responden tidak keluar nanah. Populasinya adalah seluruh ibu yang melahirkan dan kontrol dengan jumlah 43 orang. Jumlah responden 18 orang dengan teknik Accidental sampling. Teknik pengumpulan data dengan kuesioner dan observasi. Analisa data menggunakan uji Spearman's correlation.

Berdasarkan Tabel 3 didapatkan data bahwa hampir seluruhnya responden sebagai IRT sejumlah 14 responden $(77,8 \%)$

Tabel 4 Distribusi Frekuensi Responden Berdasarkan Budaya Pasien

\begin{tabular}{|c|c|c|c|}
\hline No. & Budaya & Frekuensi & $\begin{array}{c}\text { Prosentase } \\
(\%)\end{array}$ \\
\hline 1. & $\begin{array}{c}\text { Makan } \\
\text { makanan } \\
\text { tertentu }\end{array}$ & 2 & 11,1 \\
\hline 2. & $\begin{array}{c}\text { Tidak makan } \\
\text { makanan } \\
\text { tertentu }\end{array}$ & 16 & 88,9 \\
\hline & Jumlah & 18 & 100 \\
\hline \multicolumn{4}{|c|}{ Sumber : Hasil observasi data responden } \\
\hline
\end{tabular}

2. Data Khusus

Tabel 5 Distribusi Frekuensi Responden Berdasarkan Pola Makan Pasien

\begin{tabular}{cccc}
\hline No. & Kategori gizi & Frekuensi & $\begin{array}{c}\text { Prosentase } \\
(\%)\end{array}$ \\
\hline 1. & Seimbang & 17 & 94,5 \\
2. & Tidak & 1 & 5,6 \\
& seimbang & & \\
\hline & Jumlah & 18 & 100 \\
\hline
\end{tabular}

Sumber : Hasil observasi data responden 
Berdasarkan Tabel 5 didapatkan data bahwa hampir seluruhnya 17 responden $(94,5 \%)$ gizi seimbang.

Tabel 6 Distribusi Frekuensi Responden Berdasarkan fase penyembuhan luka Pasien

\begin{tabular}{lccc}
\hline N & $\begin{array}{c}\text { Penyembuhan } \\
\text { o. }\end{array}$ & Frekuensi & $\begin{array}{c}\text { Prosentas } \\
\text { e }(\%)\end{array}$ \\
\hline 1. & Fase inflamasi & 13 & 72,3 \\
2. & Fase & 3 & 16,7 \\
& proliferatif & & \\
3 & Fase maturasi & 2 & 11,2 \\
\hline
\end{tabular}

\section{PEMBAHASAN}

\section{Pola makan ibu postpartum}

Berdasarkan tabel 5 didapatkan data hampir seluruhnya dari responden tentang pola makan adalah gizi seimbang yaitu sebanyak 17 responden (94,5\%). Menurut (Matsier, 2010) bahwa faktor yang paling penting terhadap konsumsi pangan seseorang yaitu pendapatan keluarga. semakin tinggi pendapatan seseorang maka akan meningkatkan daya beli pangan. Sebaliknya, jika pendapatan seseorang rendah maka bisa mempengaruhi menurunnya daya beli pangan. Pemilihan bahan makanan biasanya berdasarkan selera seseorang daripada nilai gizi.

Berdasarkan tabel 4 menggambarkan hampir seluruhnya responden yang paling banyak yaitu tidak makan makanan tertentu sejumlah 16 responden $(88,9 \%)$. Menurut (Sediaoetama, 2010) bahwa hal ini karena faktor budaya akan mempengaruhi bagaimana cara seseorang memenuhi kebutuhan dasarnya termasuk pangan. termasuk kebutuhan terhadap pangan, meliputi jenis makanannya, cara pengolahan, dan cara penyajiannya. Menurut (Ari Istiany, 2013) bahwa faktor lingkungan mempunyai peran yang cukup besar dalam mempengaruhi perilaku makan seseorang. Lingkungan yang dimaksud yaitu lingkungan keluarga, karena kebiasaan pola makan dalam keluarga berpengaruh besar terhadap pola makan anggota keluarga.

\section{Fase penyembuhan luka episiotomi}

\begin{tabular}{ccc}
\hline Jumlah & 18 & 100 \\
\hline Sumber : Hasil observasi data responden & \\
& \\
Didapatkan data sebagian besar & 13 \\
responden $(72,3 \%)$ pada fase inflamasi
\end{tabular}

Berdasarkan uji statistik dengan menggunakan SPSS melalui uji spearman's correlation diperoleh hasil $\rho=0,046$ artinya $\mathrm{H}_{\mathrm{o}}$ ditolak sehingga ada hubungan yang bermakna antara pola makan dengan penyembuhan luka episiotomi

Berdasarkan tabel 6 didapatkan bahwa fase penyembuhan luka episiotomi sebagian besar responden dengan fase luka inflamasi yaitu sejumlah 13 responden $(72,2 \%)$, hal ini dapat dipengaruhi oleh usia. Berdasarkan tabel 1 terdapat 16 responden $(88,9 \%)$ dengan usia 2030 tahun. Menurut (Prawirohardjo, 2010) bahwa usia mempunyai pengaruh terhadap penyembuhan luka, dimana usia muda lebih cepat proses penyembuhan lukanya dibandingkan pada usia yang lebih tua. Hal ini disebabkan usia tua lebih sering menderita penyakit kronis, terjadi penurunan fungsi hati sehingga dapat mengganggu sintesis dari faktor pembekuan darah.

Proses penyembuhan luka juga dipengaruhi oleh personal hygiene, menurut (Anggraeni, 2010) bahwa setiap ibu postpartum dianjurkan untuk mengganti pembalut yaitu setelah mandi, setelah buang air kecil, dan setelah buang air besar. Pembalut yang sudah terpakai terdapat cairan yang mengandung banyak bakteri, yang dapat memicu pertumbuhan bakteri, selain mengganti pembalut juga diperlukan pembersihan pada daerah vulva, vagina, dan perineum.

\section{Hubungan Pola Makan dengan Fase Penyembuhan Luka}

Hasil uji spearman's correlation diperoleh $\rho=$ 0,046 yang mempunyai makna $\mathrm{H}_{\mathrm{o}}$ ditolak artinya terdapat hubungan pola makan terhadap 
penyembuhan luka episiotomi di BPM Hj. Umi Salamah Peterongan Jombang.

Pola makan merupakan salah satu faktor yang dapat mempengaruhi proses penyembuhan luka. Pola makan yang dianjurkan adalah dengan gizi seimbang. Gizi seimbang meliputi karbohidrat $60-70 \%, 15-20 \%$ dari protein, lemak 20-30\%, disamping itu harus cukup vitamin, mineral dan serat karena nutrien tersebut sangat mempengaruhi proses penyembuhan luka dan penggantian jaringan. Hal ini sejalan dengan penelitian (Elida, 2013) bahwa gizi seimbang berdampak positif terhadap proses penyembuhan luka. Penelitian ini juga sejalan dengan hasil penelitian yang dilakukan oleh (Dewi, 2016) bahwa dengan mengkonsumsi Protein, zat besi (fe), zinc ( $\mathrm{Zn})$ dapat mempengaruhi penyembuhan luka perineum. Penelitian yang dilakukan (Endah, 2016) bahwa terdapat hubungan antara konsumsi makanan protein hewani dengan penyembuhan luka pada ibu nifas. Protein hewani merupakan nutrien yang sangat berpengaruh terhadap penyembuhan luka perineum, karena protein sangat diperlukan untuk penggantian jaringan. Ibu nifas diharapkan lebih banyak mengkonsumsi protein hewani sehingga penyembuhan luka perineum akan semakin cepat.

\section{SARAN}

Saran dapat diberikan kepada:

Responden;

Diharapkan responden tidak melakukan pantang terhadap makanan karena untuk mempercepat proses penyembuhan luka perineum harus mengkonsumsi makanan dengan gizi seimbang terutama yang mengandung protein, serta responden harus kontrol ulang ke tenaga kesehatan untuk mengetahui proses penyembuhan lukanya.

Peneliti selanjutnya;

Dapat digunakan sebagai acuan penelitian selanjutnya dengan jumlah dan tempat yang berbeda.

Tenaga Kesehatan;

Diharapkan tenaga kesehatan dapat memberikan edukasi tentang pentingnya mengkonsumsi gizi seimbang untuk membantu mempercepat penyembuhan luka perineum.

\section{DAFTAR PUSTAKA}

Anggraeni, Y., 2010. Asuhan Kebidanan Masa

Nifas. Yogyakarta: Pustaka Rihama.

Ari Istiany, R., 2013. Gizi Terapan. Bandung: Remaja Rosdakarya.

Bahiyatun, 2009. Asuhan Kebidanan Nifas Normal. Jakarta: EGC.

Dewi, S.S., 2016. Hubungan Tingkat Konsumsi Protein, Zat Besi (Fe), Zinc (Zn) dengan Kondisi Penyembuhan Luka Perineum Derajat II Pada Ibu Nifas. Majalah Kesehatan FKUB, Volume 3 Nomor 3.

Elida, F., 2013. Faktor-Faktor Yang Mempengaruhi Lamanya Penyembuhan Luka Perineum Pada Ibu Nifas Di RSU Dr. Zainal Abidin. Banda Aceh: Sekolah Tinggi Ilmu Kesehatan U'budiyah.

Endah, d., 2016. Hubungan Konsumsi Makanan

Protein Hewani Pada Ibu Nifas dengan Penyembuhan Luka. Jurnal Involusi Kebidanan, Volume 7 Nomor 12.

Higuera.V, W.M.H., 2016. Episiotomy: Procedure, Complication, and Recovery. Holmes, D.d.B.P.N., 2011. Buku Ajar Ilmu Kebidanan. Jakarta: EGC.

Matsier, S.A., 2009. Prinsip Dasar Ilmu Gizi. Jakarta: Gramedia Pustaka Utama.

Notoatmojdo, S., 2010. Metodologi Penelitian Kesehatan. Jakarta: Rineka Cipta.

Prawirohardjo, S., 2010. Ilmu Kebidanan. Jakarta: Yayasan Bina Pustaka.

Rukiyah, A.Y., 2009. Asuhan Kebidanan 2: Persalinan. Jakarta: Trans Info Media.

Sediaoetama, 2010. Ilmu Gizi Untuk Mahasiswa dan Profesi. Jakarta: Dian Rakyat.

Yasmalizar, 2013. Hubungan Umur, Asupan Gizi dan Mobilisasi Dini Dengan Penyembuhan Luka Perineum Pada Ibu Nifas di Wilayah Kerja Puskesmas Labuhan Haji dan Puskesmas Labuhan Haji Timur Aceh Selatan. Jurnal DIY Kebidanan 